\title{
HIGANYKORRÓZIÓ JELENLÉTE A VEGYIPARBAN
}

\author{
Németh Benjámin \\ MSc hallgató, Miskolci Egyetem, Energetikai és Vegyipari Gépészeti Intézet \\ Vegyipari Gépészeti Intézeti Tanszék \\ 3515 Miskolc, Miskolc-Egyetemváros
}

Spisák Bernadett

PhD hallgató, Miskolci Egyetem, Energetikai és Vegyipari Gépészeti Intézet Vegyipari Gépészeti Intézeti Tanszék

3515 Miskolc, Miskolc-Egyetemváros, e-mail:spisak@uni-miskolc.hu

Szepesi L. Gábor

egyetemi docens, Miskolci Egyetem, Energetikai és Vegyipari Gépészeti Intézet

Vegyipari Gépészeti Intézeti Tanszék

3515 Miskolc, Miskolc-Egyetemváros, e-mail: szepesi@uni-miskolc.hu

\begin{abstract}
Absztrakt
A vegyipar hazánkban és világszerte egyaránt a kiemelt fontosságú iparágak közé tartozik. Éppen ezért fontos, hogy mindig naprakészen, a legfrissebb információk alapján hozzunk döntéseket a berendezések tervezése, üzemeltetése és karbantartása során. Elengedhetetlen, hogy tisztában legyünk a lehetséges kockázatokkal és meghibásodási mechanizmusokkal. A higany által jelentett kockázatot mindenképp figyelembe kell venni, különösen a vegyiparban, ahol akár egy apró tömörtelenség is katasztrófához vezethet. A cikkben ismertetjük a higany jelentette veszélyeket a vegyiparban, illetve kisérletekkel szemléltetjük, hogy a higany milyen formában és mértékben tudja kárositani az egyes veszélynek kitett berendezések alapanyagait. Végezetül egy hötani számitás kerül bemutatásra, amely segitségével egy közelitő érték adható meg arra, hogy egy alacsony hömérsékleten müködö höcserélö leállitását követöen a jelen lévö higany mennyi idő elteltével fog problémát jelenteni.
\end{abstract}

Kulcsszavak: higanykorrózió, amalgám korrózió, LME, kísérlet, hötani számítás

\begin{abstract}
The chemical industry in our country and also around the world is part of the high priority industries. Because of this it is very important that for the designing, operating and maintaining of the components the most recent information are used for the decision making. It is essential to be aware of the potential risks and failure mechanisms. The risks caused by mercury should be taken into account especially in the chemical industry where even a small failure can cause great catastrophes. In the article the dangers in the chemical industries caused by mercury are going to be introduced, furthermore with the help of experiments the mercury caused damages for the basic material of the equipment is going to be demonstrated. Finally a thermal calculation is presented, and with the help of it an approximate value can be given which would show that in case of the shutdown of a lowtemperature operating heat exchanger the present of mercury after how long time will cause problem.
\end{abstract}

Keywords: mercury corrosion, amalgamation, LME, experiment, thermal calculation 


\section{Bevezetés}

A higany által jelentett kockázatokra nagy figyelmet kell fordítani, különösen a vegyiparban, ahol akár egy apró tömörtelenség is katasztrófához vezethet. Hogy miért is érdemes figyelni a szénhidrogének ezen szennyező komponensére arra több példa is van, melyekből az egyik ilyen ismert meghibásodás 2004. január 1-jén történt Ausztráliában egy gázelőkészítő üzemben (Moomba gázelőkészítő üzem Santos Ltd. tulajdona). Az alapanyag magas higanykoncentrációja miatt, mely a térségre jellemző 30 $\mu \mathrm{g} / \mathrm{Nm}^{3}$ volt, egy az üzem mélyhütés rendszerében található hőcserélőbe belépő alumínium csonk felhasadt, tartalma a szabadba került és emiatt tüzeset következett be. A repedés a karima és a cső hegesztési varratából indult ki. Minden repedést és törési felületet elemi higany és/vagy oxidált elem szennyezte be, amely a higany által okozott korrózióra utal. Meghatározták, hogy a longitudinális törési felületen a repedés a folyás irányában terjedt, emellett a hosszanti repedés mindkét oldalán további repedéseket figyeltek meg. A meghibásodott alkatrész töretfelülete, az elemi higany jelenléte a törési felületen, az alumínium csonk rétegenkénti leválása, illetve az elágazó szemcseközi repedések arra utaltak, hogy a meghibásodást folyékony fém okozta elridegedés (LME - liquid metal embrittlement) okozta. Ez a meghibásodás körülbelül 6 hetes kiesést okozott a gázelökészítö üzemben, amely megközelítőleg 5,000,000 USD kárt eredményezett. Az 1. ábra szemlélteti a felhasadt csonkot. [1][2]
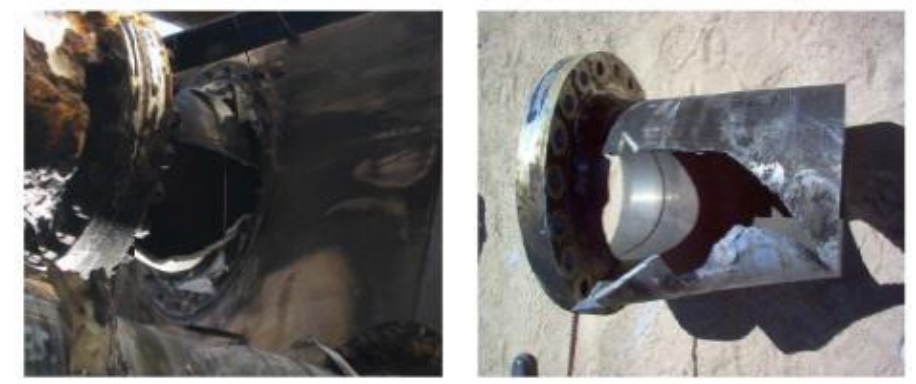

\section{1. ábra Moomba gázelökészitö üzem felhasadt csonkja [1]}

A bemutatott káreset jól szemlélteti, hogy a higany jelenléte komoly problémákat okozhat egy vegyipari üzemben, ezért fontos óvintézkedéseket tenni annak érdekében, hogy ezeket a meghibásodásokat elkerüljük. A következőkben legföképpen a higany alumíniumra gyakorolt hatását ismertetjük részletesen, majd az elvégzett kísérletek eredményei is bemutatásra kerülnek, amelyek alapanyaga alumínium volt.

\section{Higany okozta korróziós mechanizmusok}

A higany a periódusos rendszer 80. eleme, legfontosabb ásványa a cinnabarit vagy más néven higanyszulfid (HgS). Elemi állapotban ezüstös, fémszínủ cseppfolyós fém, amely jól vezeti az elektromosságot és a hőt. Igen széles hőmérséklet tartományban, egészen pontosan $-38,83^{\circ} \mathrm{C}$-tól $356,73^{\circ} \mathrm{C}$-ig képes folyadék maradni atmoszferikus nyomáson. Viszonylag nagy sürüségü, $13,6 \mathrm{~g} / \mathrm{cm}^{3}$ ezért szinte biztos, hogy elemi állapotban mindig a berendezések alsóbb szekcióiban fog megjelenni.

Az alumínium és higany között létrejövő reakció meglehetősen komplex, mellyel mind az olajiparban, mind a petrolkémiában érdemes számolni a hatékony és biztonságos üzemeltetés érdekében. Ez a típusú korrózió egyfajta spontán reakció a higany, az alumínium, a víz, illetve a levegő oxigénje között. Ha a higany akár kis mértékben is jelen lehet egyes berendezésekben, akkor azzal mindenképp 
foglalkozni kell, mivel kumulatív a hatása az alumíniumra nézve, tehát már néhány gramm is okozhat problémát lokálisan, mely a készülék tömörtelenségét vagy akár felhasadását is okozhatja.

Három alapvető korróziós mechanizmusa különböztethető meg:

- Amalgamáció - Amalgamation

- Amalgám korrózió - Amalgam Corrosion (AMC)

- Folyékony fém okozta elridegedés - Liquid Metal Embrittlement (LME)

\subsection{Amalgamáció}

Az amalgamáció egy olyan folyamat, mely során a higany vegyületeket alkot különböző fémekkel, elsősorban Al-, Au-, Ag- és Zn-el. Az alumínium esetében, az Al koncentrációja az amalgámban alacsony, ezért a károsodás behatolási mélysége csekély, ha nincs jelen víz, akkor nem számottevő a hatása az egyes berendezések alapanyagára nézve. Az alumíniumot megóvja az $\mathrm{Al}_{2} \mathrm{O}_{3}$ réteg, így a reakcióhoz a higanynak nedvesítenie kell a fém felületét. Habár ez a védő oxid réteg nem teljesen homogén, a higany nem tud átjutni a nagy felületi feszültsége miatt ezeken a mikroszkopikus repedéseken, de termikus hatások, mechanikai sérülések vagy savas/lúgos közeg jelenléte növeli a kockázatát a nagyobb repedések kialakulásának a rétegen. [3]

\subsection{Amalgám korrózió}

Az amalgám korrózió a higany és a víz együttes hatása, mely olyan korróziós folyamatot eredményez, ami igen kevés higany jelenlétében is nagymértékben károsíthatja az alumíniumot. Kis mennyiségü alumínium feloldódhat a higanyban, diffundál a higany és a nedves levegő határfelületére, majd gyorsan oxidálódik. Mivel az oxidáció eltávolítja az alumíniumot a higanytól, ezért további anyag feloldódhat és a folyamat addig halad előre még a teljes higannyal nedvesített terület oxiddá nem fog alakulni. A gyakorlatban lyukkorrózió formájában jelenik meg. A gyors oxidációhoz szükség van vízre, ennek hiányában kicsi a reakciósebesség. Például hőcserélők esetében e korróziós mechanizmus következménye lehet a lemezek károsodása és azok szétválása egymástól, továbbá hirtelen nyomásesést, a két közeg keveredését és az üzemi paraméterek megváltozását eredményezheti. Az amalgám korrózió mechanizmusát szemlélteti a 2. ábra. [3]

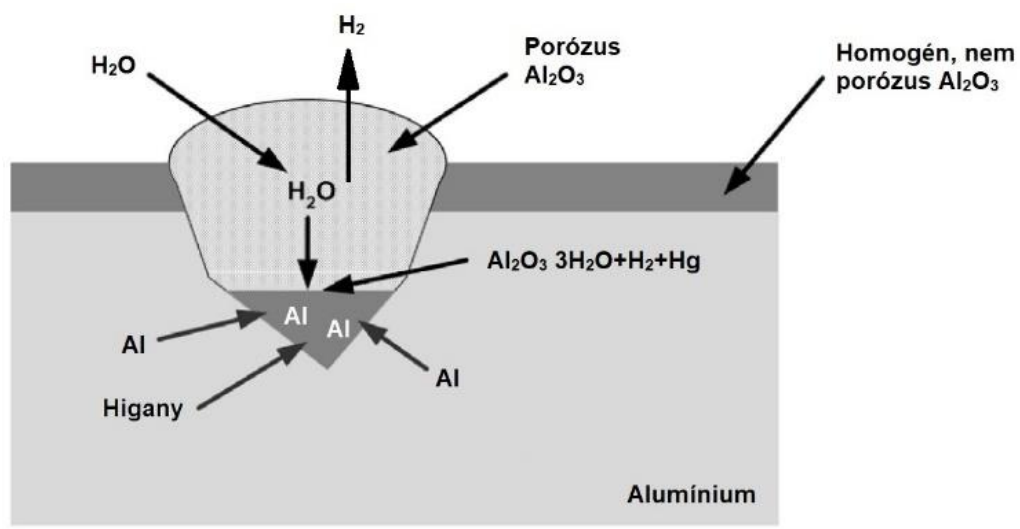

2. ábra Az AMC mechanizmusa [3] 
Az alábbi tényezők szükségesek az AMC kialakulásához:

- A higany elemi formában, cseppfolyós halmazállapotban legyen jelen

- Az alumínium felületét nedvesítse

- A nedvesítéshez szükséges az oxid-réteg sérülése, oxid kifáradás

- Víz jelenléte

A folyamat során képződő fehéres, szürkés színű, hamuszerü kiválásokat lehet megfigyelni az alumínium felületén. Endoszkópos vizsgálatoknál fehér lerakódásokat érdemes keresni, illetve, ha van rá lehetőség, akkor mintavételezéssel, majd laborban történő vizsgálattal célszerủ megállapítani az anyag mivoltát.

\subsection{Folyékony fém okozta elridegedés - LME}

Az LME a fémeknél egy komplex tönkremeneteli mechanizmus, mely figyelmeztető jel nélkül, gyorsan végbemegy. Az alapfém ridegedését okozza, mely során megváltoznak annak a mechanikai tulajdonságai és ez a készülék alapanyagának töréséhez, köpenyének és csonkjainak felhasadásához vezethet. Elsősorban az alumíniumötvözetekre jelent veszélyt, kiváltképp a mangán és magnézium tartalmú változatoknál. Leginkább a hegesztési varratok mentén jelent kockázatot, ezért itt érdemes fokozottan ellenőrizni a készülékeket. Az API-571-ben, mint korróziós mechanizmust az 52-es számmal jelölik. [4][5]

A leggyakoribb folyékony fém ridegedést okozó elem a higany, mely nem csak az alumíniumot, hanem bizonyos mértékben a $\mathrm{Cu}, \mathrm{Ti}, \mathrm{Ni}, \mathrm{Fe}, \mathrm{Zn}$ ötvözeteket is ridegítheti. Az LME-nek több típusát különböztethetjük meg. Általában csak a ridegedést okozó atomok adszorpciójából keletkező repedések keletkeznek a feszültségnek kitett zónákban, diffúzió nem történik. A Hg-Al rendszer esetében a ridegedést okozó atomok diffúziója is végbemegy, ezért ez egy külön kategóriába tartozik. A folyékony fém által okozott repedések intergranuláris módon terjednek a nagy szilárdságú alumíniumötvözetekben. Ha a repedések már megjelentek, akkor rendkívül gyors repedésterjedésre számíthatunk, melyek általában a szemcsehatárok mentén alakulnak ki. A folyékony fém bekerül a repedéscsúcsokba, növelve ezzel a terjedési sebességüket. A repedéscsúcsoknál adszorbeálódó $\mathrm{Hg}$ atomok gyengítik az alumínium interatomikus kötéseit és megkönnyíti a repedés növekedését, azáltal, hogy lehetővé teszik ezeknek a kötéseknek a könnyebb megbontását. A folyamathoz nem szükséges nedvesség (víz), habár jelenléte gyorsíthatja a reakciót. A legtöbb esetben, az LME által okozott meghibásodás valamilyen szivárgás egy hegesztési varrat közelében, de előfordulhat, hogy a keletkezett repedések kiterjednek nagyobb távolságokra, mely akár fel is repesztheti a nyomástartó berendezést. [4]

\section{Amalgám korróziós kísérlet}

A kísérlet során a 3003-as és az 5083-as alumínium ötvözetet vizsgáltuk meg. Ezek nagyszilárdságú ötvözetek, melyek szilárdsága a hozzáadott magnéziumnak, mangánnak és réznek köszönhető. Habár a metallurgiai tulajdonságait nagyban növeli az anyagnak, viszont érzékenyebbé teszi a folyékony fém ridegedéssel szemben. A következőkben kétféle kísérletet mutatunk be, az első esetben a reakció során a víz nem került pótlásra, ebben az esetben az amalgám korrózió és az amalgamáció hasonlítható össze egymással, ahol a kísérlet lefolyása 27 órát vett igénybe, míg a második esetben a reakcióhoz szükséges víz 6 óránként pótlásra került. A kísérlet hossza 6 nap volt. 


\subsection{Amalgám korróziós kísérlet reakcióhoz szükséges víz pótlása nélkül}

A kísérlet során egy $105 \times 75 \times 12$ mm-es alumínium darabra 4 db $10 \mathrm{~mm}$ átmérőjű és $3 \mathrm{~mm}$ mélységü furatot készítettünk. Ezekbe furatonként 1,2 gramm cseppfolyós elemi higany került elhelyezésre. A furatok elkészítése két okból volt szükséges. Egyrészt, hogy a higany a megfelelö pozícióban maradjon, másrészt, hogy az alumínium-oxid védőréteg megsérüljön az anyag felületén, ez a reakció létrejöttéhez szükséges. A 4. furathoz $5 \mathrm{ml}$ vizet adtunk azért, hogy az amalgám korrózióhoz szükséges feltételek teljesüljenek. Annak érdekében, hogy kiderüljön mikor lép legkönnyebben reakcióba a két fém egymással az egyes furatok elkészítése után a higany ráhelyezése előtt azok felületét hagytuk a levegővel érintkezni adott ideig.

1. táblázat. Alumínium-oxid réteg regenerálódására hagyott idők

\begin{tabular}{|c|c|}
\hline Furat sorszáma & Szabad levegön eltöltött idő [s] \\
\hline 1. eset & 300 \\
\hline 2. eset & 120 \\
\hline 3. eset & 10 \\
\hline 4. eset & 10 \\
\hline
\end{tabular}

A 3. ábra az elvégzett kísérlet elörehaladását mutatja be, amelyeket a következökben részletezünk.

1. Kísérlet előkészítése

2. A reakció 1 óra eltelte után: A kísérlet megkezdése után egy órával már látható jelei voltak az amalgámképződésnek a 2. és 3 . furat esetében. Itt egyszerü amalgamáció figyelhető meg. A 4. furatnál gázképződést is tapasztalható, mely nem más, mint a reakció során keletkezett hidrogén.

3. A reakció eltelte 7 óra után: A 4. furat esetében a reakció már igen erőteljes. keletkezett alumínium-oxid keveredett a vízzel és egyfajta szürkés masszává kezdett összeállni. Az 1-es, 2-es és 3-as furat állapota nem változott, egyrészt mivel nem érte őket víz, másrészt mert az amalgamáció lassabb, kevésbé ártalmas folyamat

4. Keletkezett porózus alumínium-oxid 27 óra elteltével: Ezen kísérlet során a víz nem került pótlásra, ezért a 27. órát követően a reakció megállt a 4. furat esetében. A higany csepp továbbra is megvolt a képződött réteg alatt, tehát annak mennyisége elhanyagolható mértékben csökkent a reakció során. Ez annak is köszönhető, hogy a reakció közben a higany újraképződik. A keletkezett korróziós termék fehéres-szürkés színü, szálas, hamuhoz hasonlítható porózus anyag, mely lényegében alumínium-oxid. Igen könnyen eltávolítható az alumínium felületéröl.

5. Megtisztított furatok: A megtisztítás során a higany eltávolítását követően kénpor segítségével semlegesítettük. Látható, hogy a legnagyobb mértékủ károsodást a 4-es számú furat szenvedte el, amely bizonyítja az alapfeltevéseket, hogy az amalgám korrózió sokkal nagyobb veszélyt jelent az alumíniumra nézve, mint az amalgamáció.

6. A furatok 12x-es nagyításban: a nagyításból következtetni lehet arra, hogy milyen gyorsan regenerálódott egy olyan vastagságú oxid-film réteg a furat felületén, hogy az megóvja az alumíniumot a higanytól. Látható, hogy az 1 . és 2 . furat kevésbé károsodott, míg a 3 . már nagyobb mértékben, de ez sem számottevő. A 4. furatnál már jelentős a kár, mely a víz jelenlétének kö- 
szönhető. A fúró által keletkezett barázdák is eltűntek, olyan mértékű volt a károsodás 27 óra alatt.

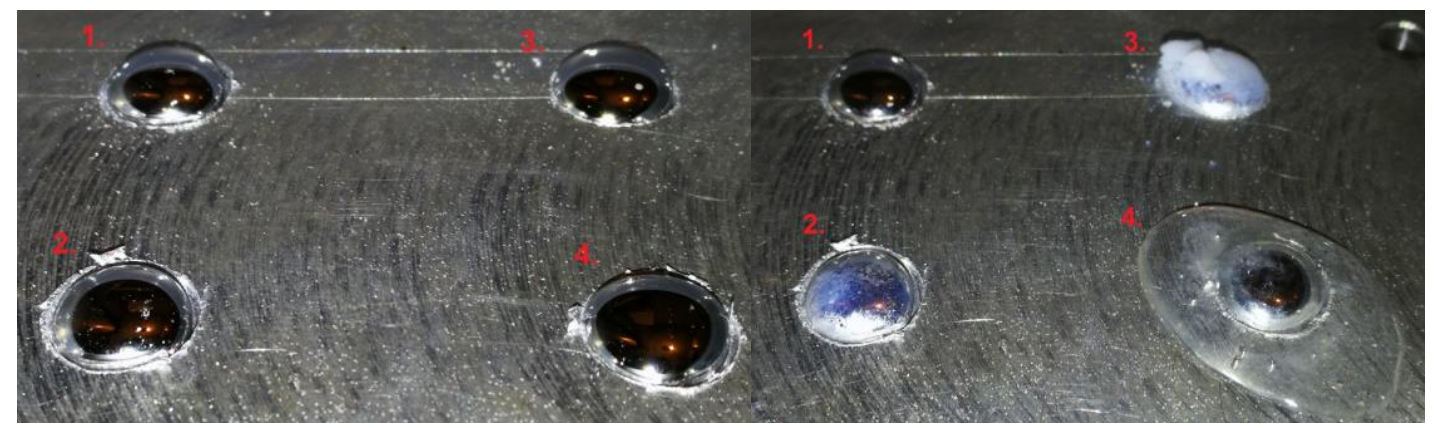

1. 2.

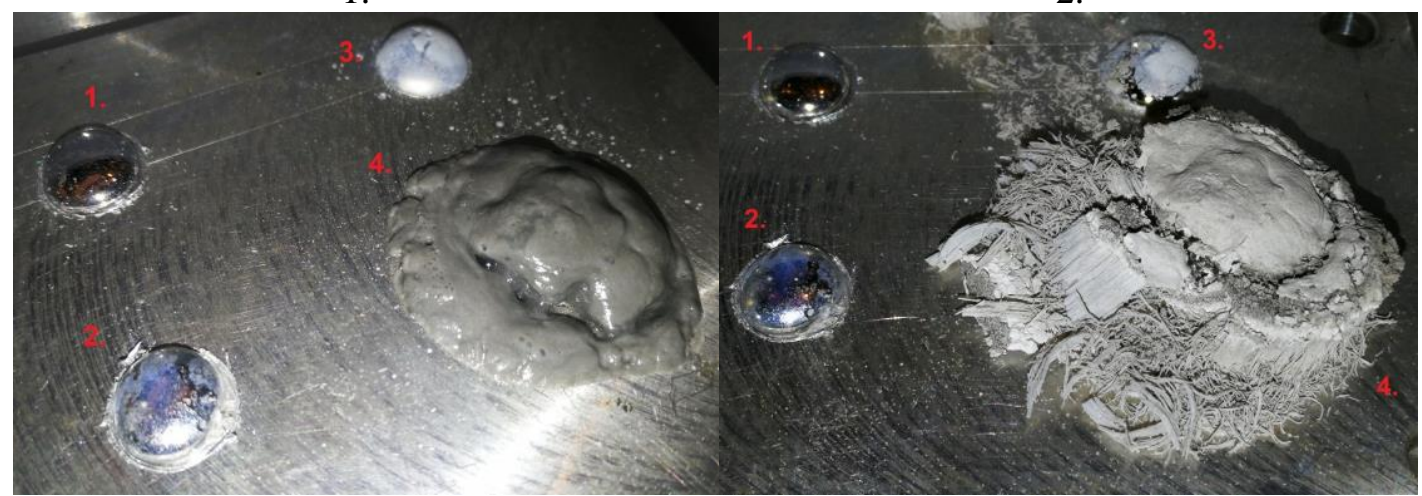

3.

4.

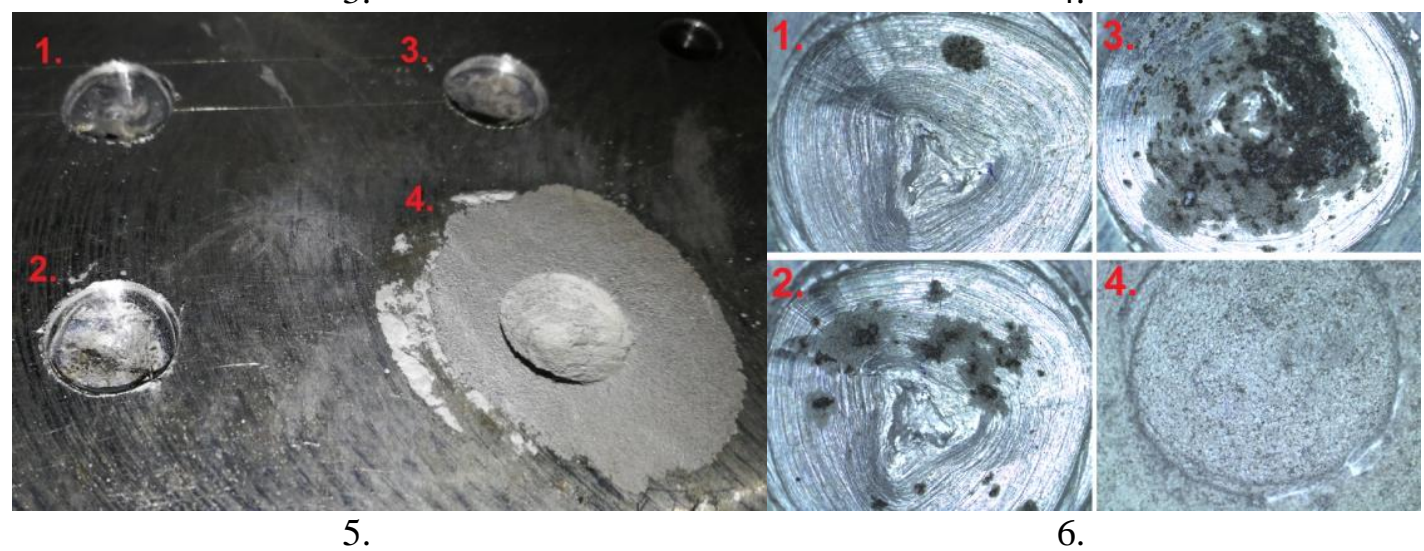

3. ábra Elvégzett kisérlet lépései

\subsection{Amalgám korróziós kísérlet reakcióhoz szükséges víz pótlásával}

A kísérletet víz pótlásával is elvégeztük, ahol az elözőhöz hasonlóan az alumínium tömbben furatot készítettünk, amelybe 1,2 gramm higany mellett $5 \mathrm{ml}$ vizet raktunk. A víz 6 óránként került pótlásra, így a kísérlet 6 napot vett igénybe. A károsodás egyes stádiumait a 4. ábra szemlélteti. 

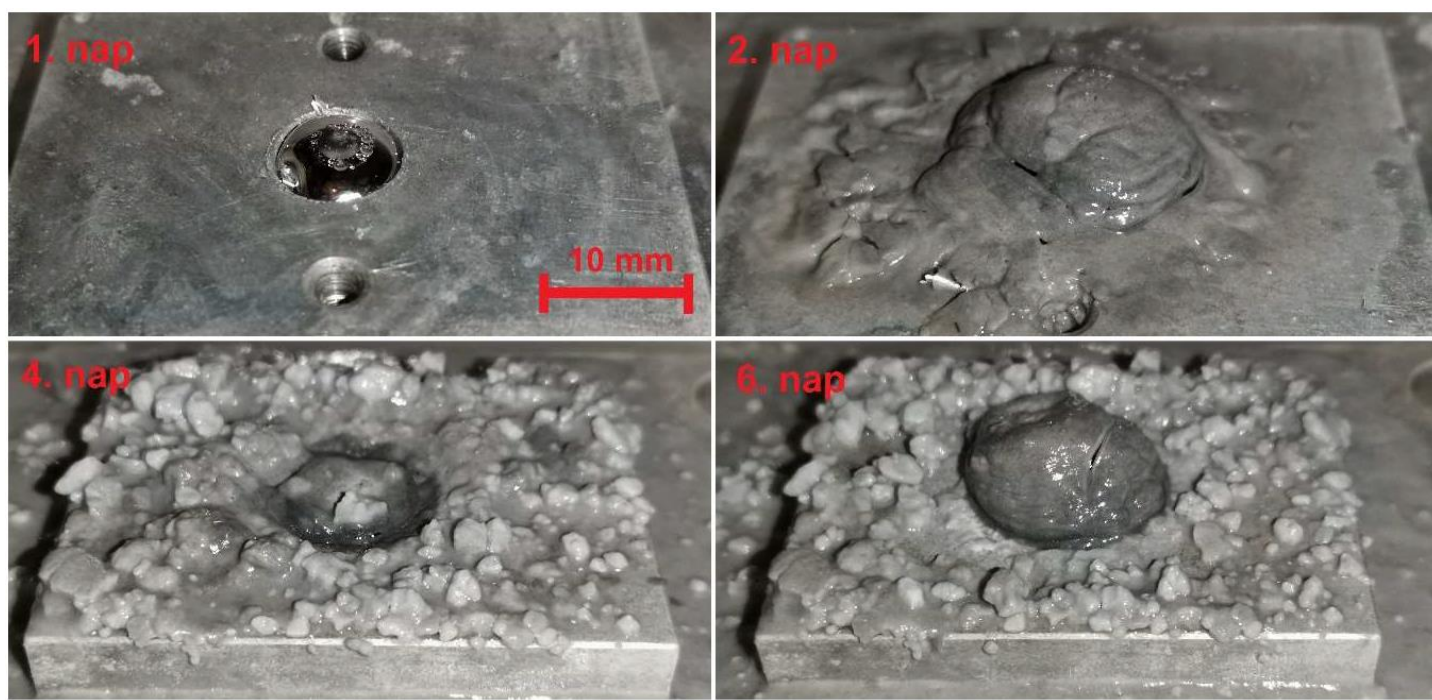

4. ábra A reakció egyes stádiumai a kisérlet során

Látható, hogy a víz rendszeres pótlása miatt a keletkezett $\mathrm{A} 12 \mathrm{O} 3$ apró törmelékké állt össze. Ezt a 4. naptól lehetett megfigyelni. A víz pótlása során a furatból elhordta a keletkezett korróziós terméket és új képződött a helyén. A próbadarab megtisztítása, illetve a higany biztonságos eltávolítása után az 5. ábra szemlélteti a keletkezett kár a furaton. Viszonyítási alapként mellette a furat kísérlet elötti állapota látható.

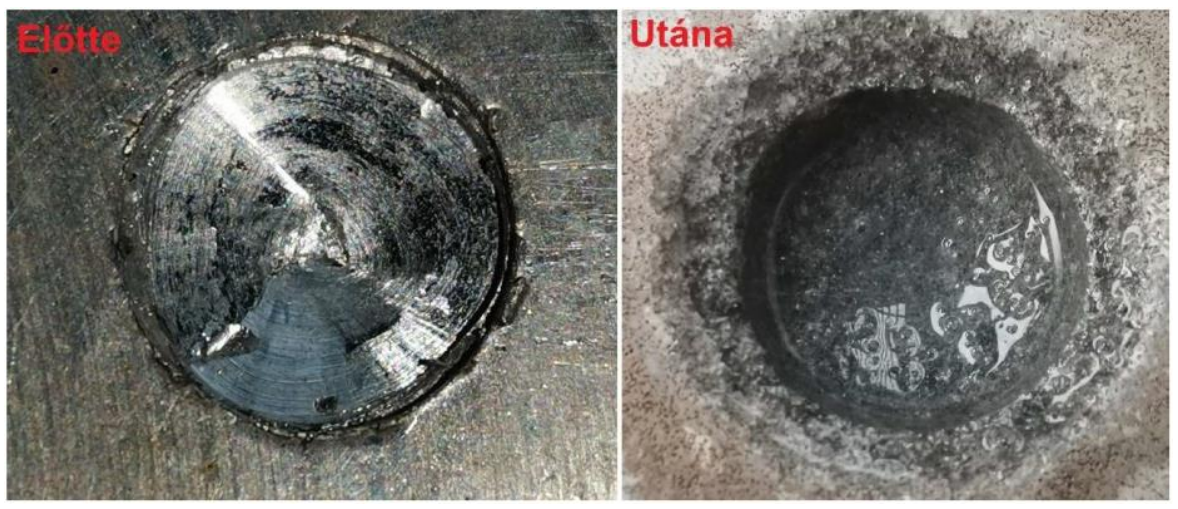

5. ábra A furat állapota a kísérlet elött és után

Az alumíniumon az oxid réteg sérülése, a cseppfolyós elemi higany és a víz együttes jelenlétének hatására jelentősen károsodott a furat 6 nap alatt. Tehát, ha elegendő víz áll rendelkezésre, akkor hosszabb idő alatt jelentős mértékủ anyagfogyás is tapasztalható. A 6. ábrán látható, hogy a furat élei teljes mértékben eltüntek, mintha abrazív vagy agresszív közegben lett volna elhelyezve. A fúró által keletkezett barázdák is teljesen eltűntek, ez is szemlélteti az anyagfogyás mennyiségét. 

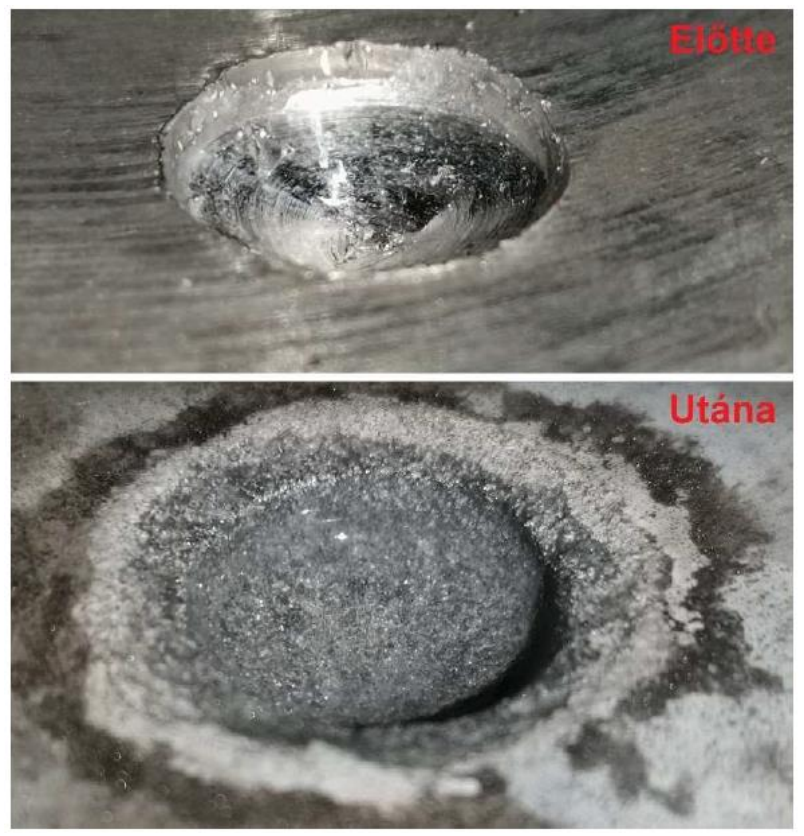

6. ábra A furat állapota a kísérlet elött és után egy másik szögböl

Ezek a kísérletek megmutatták, hogy milyen káros lehet a higany és a víz jelenléte az alumíniumra nézve, ha annak valamilyen okból kifolyólag megsérült a felületén lévő oxid rétege, továbbá képi anyagot biztosít az ilyen típusú károsodás megjelenéséről, ezzel segítve a berendezés vizsgálatait és a higany által okozott meghibásodások felismerését.

\section{Higany korrózió kialakulására alkalmas feltételek hőtani meghatározása időben vál- tozó matematikai modell segítségével}

A szakirodalomban a higannyal való szennyezettséget kritikus súlyosságú kockázatnak tekintik. Egy 1-től 9-ig tartó kockázati tényező skálán (9=nagyon alacsony kockázat) 3-as besorolású azokban az üzemekben, ahol nincs higanyfogó egység telepítve, ezért ahol higanytartalmú alapanyag lehet jelen erősen ajánlott olyan óvintézkedéseket alkalmazni, mellyel csökkenthető ez a kockázati tényező. Egyik ilyen példa az alumínium lemezes hőcserélők higannyal való szennyezettsége, melynek meghatározása és attól való mentesítése igen nehéz feladat. A kockázatelemzési folyamat több részből állhat, úgy, mint a lerakódott/felgyülemlett higanymennyiség becslése, kritikus helyek felkeresése a rendszerben, ahol lerakódhat higany, anyagminőségek és előállítás módok figyelembevétele, a hőmérséklet hatására bekövetkező feszültségek vizsgálata, valamint korróziós vizsgálatok. Oxid kifáradási görbékkel számon tartható, illetve becsülhető az adott hőcseréló állapota. A karbantartási események vizsgálatával megtudhatjuk, hogy hányszor volt leállítva a hőcserélő, azaz, hogy hányszor volt üzemi hömérsékleten kívül, valamint hányszor csökkentették, illetve növelték a nyomást. Figyelembe kell venni az áramló közeg típusát is, el kell dönteni, hogy abrazív-e vagy sem, tudja-e károsítani az oxid réteget vagy nem. Statisztikailag az oxid kifáradás miatti meghibásodás valószínüsége szorosan összefügg az adott alumínium hőcserélő üzemidejének hosszával és a leállások számával. 
Léteznek olyan alumínium höcserélők, amelyek esetén a higany csak leállás követően okozhatnak problémát, mivel üzemelés során a rendszerben lévő alacsony hőmérsékletek miatt a higany csak szilárd állapotban van jelen, azonban a leállások során a hőcserélő felmelegedésével a higany cseppfolyóssá alakul, amely már komoly problémákat okozhat abban az esetben, ha a rendszer alsó részein lerakódik.

Ennek a vizsgálatára egy egyszerü matematikai modellt alkottunk, mely segítségével meghatározható egy adott hőcserélőben lévő folyadék felmelegedése a környezeti hatások miatt. Az energiára vonatkozó fundamentális transzportegyenlet megoldásával lehet azt az idöt meghatározni, amennyi alatt a höcserélöbe bezárt folyadék felmelegszik a higany olvadáspontjára.

A fundamentális egyenleg egyszerüsített alakja [6]:

ahol

$$
V \cdot \rho \cdot c \frac{\partial T}{\partial \tau}=Q_{B e},
$$
$V$ a bezárt folyadék térfogata $\left[\mathrm{m}^{3}\right]$,
$\rho$ a bezárt folyadék sürüsége $\left[\mathrm{kg} / \mathrm{m}^{3}\right]$,
$c$ a bezárt folyadék fajhője [J/kgK],
$T$ a folyadék mindenkori hömérséklete $[\mathrm{K}]$,
$\tau$ az idö [s],
$Q_{B e}$ a rendszerbe érkező hőmennyiség [W].

A beérkező hőmennyiség számítását az alábbi összefüggéssel tudjuk meghatározni:

$$
Q_{B e}=U \cdot A \cdot \Delta T
$$

ahol

$U$ a höátviteli tényező $\left[\mathrm{W} / \mathrm{m}^{2} \mathrm{~K}\right]$,

$A$ a höátadó felület $\left[\mathrm{m}^{2}\right]$,

$\Delta T$ a hajtóerő [K].

A hőátvitel során a folyadék oldalakon szabadkonvekció fog megvalósulni, a készülék falában hővezetés és adott esetben a szigetelésben is. Az így kialakuló höátviteli tényező meglehetősen kis értékü lesz [7], a szimulációs számításaink során $5 \mathrm{~W} / \mathrm{m}^{2} \mathrm{~K}$-nek feltételeztük. A hajtóerő a számítás során minden esetben az aktuális időpillanatban a készülékben lévő folyadék és a környezet közötti hőmérséklet különbsége. Euler módszert alkalmazva a transzportegyenlet egy egyszerủ algebrai egyenletként megoldható.

Az alábbi táblázatban összefoglaljuk, hogy különböző környezeti hőmérsékletek esetén milyen idő szükséges ahhoz, hogy a folyadékban lévő szilárd állapotú higany elérje az olvadáspontját. A mintaszámításnál az alábbi alapadatokat vettük figyelembe:

2. táblázat. Alapadatok

\begin{tabular}{|c|c|c|}
\hline Megnevezés & Jel & Érték \\
\hline Höcserélö felület & $\mathrm{A}$ & $4 \mathrm{~m}^{2}$ \\
\hline Folyadék térfogat & $\mathrm{V}$ & $1 \mathrm{~m}^{3}$ \\
\hline Folyadék fajhöje & $\mathrm{c}$ & $2000 \mathrm{~J} / \mathrm{kgK}$ \\
\hline Higany olvadáspontja & $\mathrm{T}_{\mathrm{olv}}$ & $-38^{\circ} \mathrm{C}$ \\
\hline
\end{tabular}




\section{\begin{tabular}{|l|l|l}
\hline Hőátviteli tényező & $\mathrm{k}$ & $5 \mathrm{~W} / \mathrm{m}^{2} \mathrm{~K}$
\end{tabular}}

Ha feltételezzük, hogy a hőcserélőben lévő folyadék kezdeti időpontban lévő hőmérséklete $-40^{\circ} \mathrm{C}$, a különböző környezeti hőmérsékleteken elvégzett számítások eredményeit a 3. táblázatban foglaltuk össze:

3. táblázat. Eredmények

\begin{tabular}{|c|c|}
\hline Környezeti hőmérséklet & $\begin{array}{c}\text { Olvadáspont elérésé- } \\
\text { hez szükséges idő }\end{array}$ \\
\hline-10 & $6882 \mathrm{~s}$ \\
\hline 5 & $5869 \mathrm{~s}$ \\
\hline 10 & $4072 \mathrm{~s}$ \\
\hline 30 & $2892 \mathrm{~s}$ \\
\hline
\end{tabular}

\section{5. Összegzés}

A cikkben a higany által okozott korróziós mechanizmusokkal foglalkoztunk. Az elvégzett irodalomkutatás alapján a legnagyobb veszélyt a folyékony fém okozta ridegedés (LME) és az amalgám korrózió (AMC) jelenti, ezért ezeket a mechanizmusokat részletesebben megvizsgáltuk. Az amalgám korrózióra több kísérletet is elvégeztünk, amelyek alátámasztották a szakirodalomban fellelhető eredményeket, hogy a higany vízzel történő érintkezése alumínium berendezésekben komoly meghibásodásokat okozhat. Végezetül a higany korrózió kialakulására alkalmas feltételeket időben változó matematikai modell segítségével határoztuk meg, mivel vannak olyan berendezések, amelyben üzemelés során a higany szilárd formában van jelen, mint például mélyhütés rendszerekben található alumínium lemezes hőcserélőknél. Ezekre a berendezésekre kizárólag a folyékony halmazállapotú elemi higany jelent veszélyt, mivel ez az egyik alapfeltétele a degradációs folyamat kialakulásának. E feltétel nem minden esetben teljesül, mivel némely hőcserélő a higany fagyáspontja alatt üzemel, így normál üzemvitel mellett nem okozhat gondot, viszont a problémát az jelenti, ha leáll az üzem és a berendezések felmelegednek olyan hőmérsékletre, melyen a higany felolvad, vagyis $-38{ }^{\circ} \mathrm{C}$ fölé, így az elkészített modell segítségével meghatározható, hogy egy adott berendezés milyen gyorsan éri el ezt a hőmérsékletet. Ha ezek a kritikus idők rendelkezésre állnak egy adott üzem összes hőcserélőjére, akkor ennek segítségével egy veszélyességi sorrend állítható fel, vagyis egy esetleges leállást követen ismert az üzemeltető számára, hogy mely berendezések károsodhatnak a legrövidebb idő alatt, így ezek ellen óvintézkedések tehetöek.

\section{Irodalom}

[1] https://abduh137.wordpress.com/2008/05/01/the-50-major-engineering-failures-1977-2007-part4/ (Letöltve: 2020.02.10.)

[2] https://www.hrlt.com.au/blog/effects-of-mercury-on-an-aluminium-heat-exchanger-in-a-naturalgas-plant (Letöltve: 2020.02.10.)

[3] Wilhelm S.M.: Risk Analysis for Operation of Aluminum Heat Exchangers Contaminated by Mercury; Proc. Safety Prog. 2009, 28:259-266 https://doi.org/10.1002/prs.10322 
[4] Nicholas M.G., Old C.F.: Liquid metal embrittlement; Journal of Material Science 1979, 14:1-18 https://doi.org/10.1007/BF01028323

[5] American Petroleum Institute: Damage Mechanisms Affecting Fixed Equipment in the Refining Industry; API Recommended Practice 571; (2011)

[6] Hangos, K.M., Cameron, I.T.: Process modelling and model analysis. Ed: Academic Press, London, UK., pp. 1-543 ISBN 0-12-156931-4 (2001)

[7] Perry- Chemical engineering handbook, 8th ed. Section 5. https://doi.org/10.1036/0071511288 